Provided for non-commercial research and education use. Not for reproduction, distribution or commercial use.

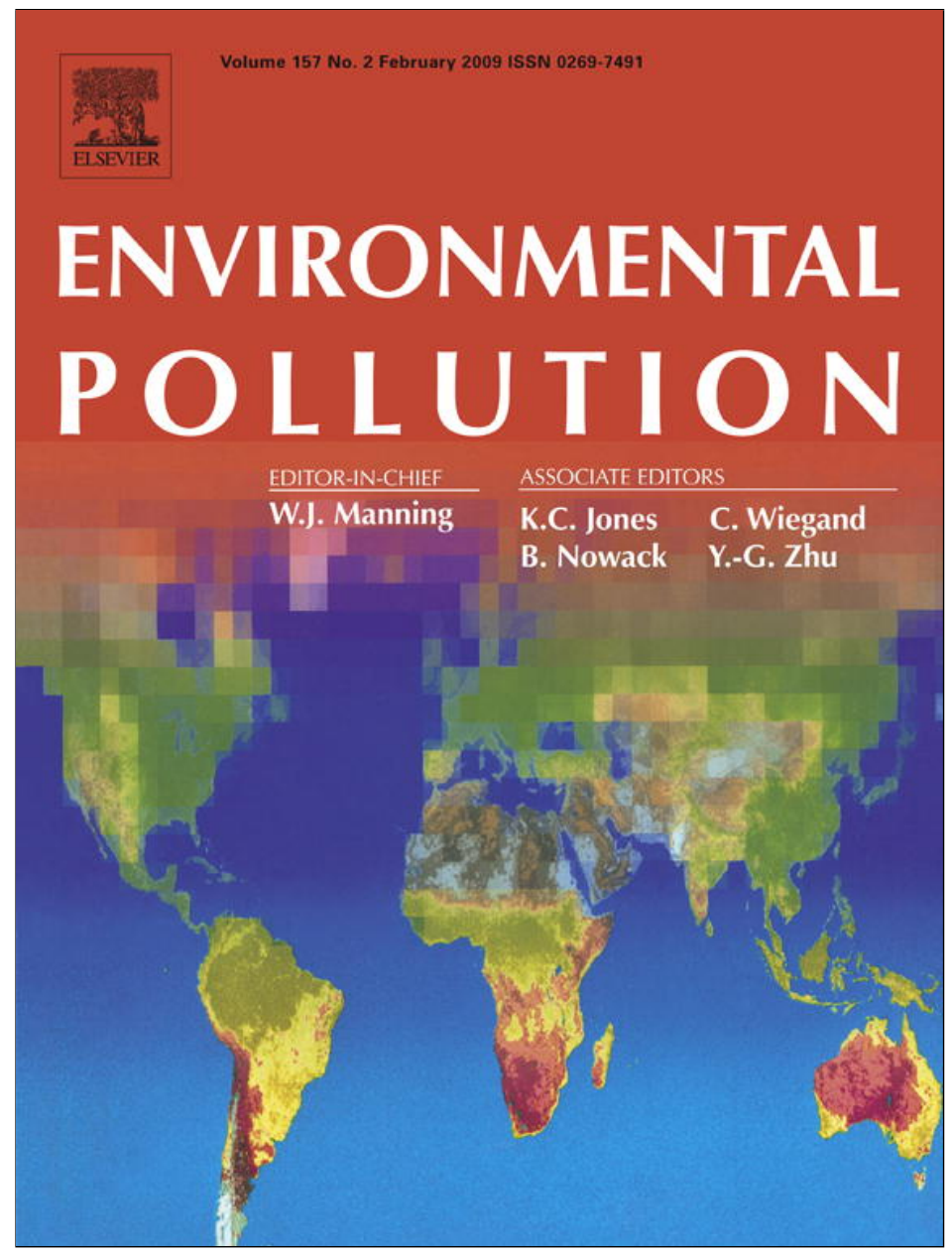

This article appeared in a journal published by Elsevier. The attached copy is furnished to the author for internal non-commercial research and education use, including for instruction at the authors institution and sharing with colleagues.

Other uses, including reproduction and distribution, or selling or licensing copies, or posting to personal, institutional or third party websites are prohibited.

In most cases authors are permitted to post their version of the article (e.g. in Word or Tex form) to their personal website or institutional repository. Authors requiring further information regarding Elsevier's archiving and manuscript policies are encouraged to visit:

http://www.elsevier.com/copyright 


\title{
Inter-species differences for polychlorinated biphenyls and polybrominated diphenyl ethers in marine top predators from the Southern North Sea: Part 1. Accumulation patterns in harbour seals and harbour porpoises
}

\author{
Liesbeth Weijs $^{\mathrm{a}, \mathrm{b}}$, Alin C. Dirtu ${ }^{\text {b,c }}$, Krishna Das ${ }^{\mathrm{d}}$, Adriana Gheorghe ${ }^{\mathrm{b}, \mathrm{e}}$, Peter J.H. Reijnders ${ }^{\mathrm{f}}$, \\ Hugo Neels $^{\mathrm{b}}$, Ronny Blust ${ }^{\mathrm{a}}$, Adrian Covaci ${ }^{\mathrm{a}, \mathrm{b}, *}$ \\ ${ }^{a}$ Laboratory of Ecophysiology, Biochemistry and Toxicology, Department of Biology, University of Antwerp, Groenenborgerlaan 171, 2020 Antwerp, Belgium \\ ${ }^{\mathrm{b}}$ Toxicological Centre, University of Antwerp, Universiteitsplein 1, 2610 Wilrijk, Belgium \\ ${ }^{\mathrm{c}}$ Department of Inorganic and Analytical Chemistry, "Al. I. Cuza" University of Iassy, Carol I Bvd. No 11, 700506 Iassy, Romania \\ ${ }^{\mathrm{d}}$ Laboratory for Oceanology-MARE Center, University of Liège B6C, 4000 Liège, Belgium \\ e Department of Analytical Chemistry, Faculty of Chemistry, University of Bucharest, Soseaua Panduri 90-92, 050663 Bucharest, Romania \\ ${ }_{\mathrm{f}}^{\mathrm{f}}$ Institute for Marine Resources and Ecosystem Studies, Department of Ecology, PO Box 167, 1790 AD Den Burg, The Netherlands
}

Harbour porpoises and harbour seals present differences in the accumulation of polychlorinated biphenyls and polybrominated diphenyl ethers.

\section{A R T I C L E I N F O}

\section{Article history:}

Received 28 March 2008

Received in revised form 31 August 2008

Accepted 14 September 2008

\section{Keywords:}

PCBs

PBDEs

Profiles

Accumulation

Harbour seal

Harbour porpoise

Marine mammals

Southern North Sea

\begin{abstract}
A B S T R A C T
Harbour porpoises (Phocoena phocoena) and harbour seals (Phoca vitulina) are two representative top predator species of the North Sea ecosystem. The median values of sum of 21 polychlorinated biphenyl (PCB) congeners and sum of 10 polybrominated diphenyl ether (PBDE) congeners were $23.1 \mu \mathrm{g} / \mathrm{g}$ lipid weight (lw) and $0.33 \mu \mathrm{g} / \mathrm{g} \mathrm{lw}$ in blubber of harbour seals $(n=28)$ and $12.4 \mu \mathrm{g} / \mathrm{g}$ lw and $0.76 \mu \mathrm{g} / \mathrm{g}$ lw in blubber of harbour porpoises $(n=35)$, respectively. For both species, the highest PCB concentrations were observed in adult males indicating bioaccumulation. On the contrary, the highest PBDE concentrations were measured in juveniles, likely due to better-developed metabolic capacities with age in adults. A higher contribution of lower chlorinated and non-persistent congeners, such as CB 52, CB 95, CB 101 , and CB 149, together with higher contributions of other PBDE congeners than BDE 47, indicated that harbour porpoises are unable to metabolize these compounds. Harbour seals showed a higher ability to metabolize PCBs and PBDEs.
\end{abstract}

(C) 2008 Elsevier Ltd. All rights reserved.

\section{Introduction}

Since several decades, it has been shown that pollution puts a great pressure on the marine environment. Local input through rivers and runoff, together with (long-range) atmospheric transport are major factors governing the presence and distribution of anthropogenic contaminants, such as polychlorinated biphenyls (PCBs) and polybrominated diphenyl ethers (PBDEs) in the aquatic environment, including seas and oceans (Tanabe et al., 1994; AMAP, 2004; Law et al., 2003, 2006a). Due to their physical and chemical properties, these contaminants are capable of entering aquatic ecosystems and as a consequence, they can be a threat to organisms in every trophic level (Tanabe et al., 1994; Boon et al., 2002). Among

\footnotetext{
* Corresponding author. Toxicological Centre, University of Antwerp, Universiteitsplein 1, 2610 Wilrijk, Belgium. Fax: +32 38202722.

E-mail address: adrian.covaci@ua.ac.be (A. Covaci).
}

them, PCBs are the most monitored contaminants in marine mammals (Duinker et al., 1989; Hutchinson and Simmonds, 1994; Vetter et al., 1996; Severinsen et al., 2000; Kajiwara et al., 2001). PCBs have been used for a variety of applications including dielectric fluids for transformers, plasticisers, or components in glue and paint. Although their production was banned since the end of the 1970s, PCBs can still be found in wildlife. Recently, attention has been drawn towards the accumulation and effects of new persistent contaminants, such as PBDEs, in marine mammals. The PBDE commercial mixtures contain fewer congeners than the corresponding $\mathrm{PCB}$ mixtures. PBDEs are used as flame retardants in textiles, furniture, and plastics (de Boer et al., 2000; Birnbaum and Staskal, 2004). The use of the penta- and octa-BDE technical mixtures is currently banned in Europe (EU-directive 2002/95/EC). Several adverse effects observed in wildlife, such as endocrine dysfunction, reproductive failure, immunological impairment, developmental stress and genotoxic disorders have been linked to the presence of these contaminants (Reijnders, 1986; Gauthier 
et al., 1999; Fair and Becker, 2000; Damstra et al., 2002; Beineke et al., 2005; Das et al., 2006).

Marine mammals are top predators in aquatic food chains and are, thus, particularly vulnerable and sensitive to contaminants which are persistent in the environment and which can accumulate in high concentrations. In marine mammals, uptake of organic contaminants occurs mainly through their diet (Borgå et al., 2004), while routes such as placental transfer and lactation may affect the offspring at a critical stage of their development (Duinker and Hillebrand, 1979; Debier et al., 2003a,b; Wolkers et al., 2004).

Harbour seals (Phoca vitulina) and harbour porpoises (Phocoena phocoena) are two representative top predator species for the North Sea ecosystem. Their long life spans and population density make them suitable for monitoring pollution in the North Sea. These two species share an extensive part of their diets, such as benthic and pelagic fish species (Hall et al., 1998; Santos and Pierce, 2003). However, comparisons between the harbour seals and porpoises in the accumulation of contaminants must be made with caution. Harbour seals are more sedentary, while porpoises seem to move over larger distances and, as a consequence, concentrations of contaminants in these two species may reflect contamination on a different spatial scale (Vetter et al., 1996; Law et al., 2002; Das et al., 2004; Fontaine et al., 2007).

The movement of lipophilic contaminants in marine mammals is strongly influenced by the lipid dynamics inside the body. The investigation of the presence of PCBs and PBDEs in blubber, the subcutaneous fat layer, is therefore important to assess the overall contamination status of the animals. Blubber provides insulation for the body and acts as a metabolic energy storage site (Dunkin et al., 2005). This latter role is important in the mobilization of lipids and lipophilic contaminants, depending on the animal's condition.

In the present study, we have investigated the accumulation and biomagnification of PCB and PBDE congeners in blubber of harbour seals and harbour porpoises from the Southern North Sea. An overall objective of this study was to gain knowledge about the metabolic capacities of both harbour seals and porpoises. The first part involves the study of PCB and PBDE concentrations and profiles and their species-dependent relationship with age and gender. In the second part (Weijs et al., 2009), biomagnification factors for individual PCB and PBDE congeners were calculated and the influence of various factors, such as octanol-water partition coefficients and trophic position assessed through measurements of ${ }^{15} \mathrm{~N}$ stable isotopes, was discussed.

\section{Materials and methods}

\subsection{Samples}

Necropsy was carried out at the Department of Veterinary Pathology (Liege University) and at the IMARES Research Center at Texel (The Netherlands). Blubber samples were collected from 35 harbour porpoises and 28 harbour seals stranded or bycaught in the Southern North Sea between 1999 and 2004. The animals were dissected and tissues were archived at the Laboratory of Oceanography, University of Liege (Belgium) at $-20^{\circ} \mathrm{C}$. Biological parameters, such as age, gender, weight and blubber thickness, were also recorded (standard procedure in Jauniaux et al., 2002 and Das et al., 2004) and given in Table 1. Age classification ( $<3$ years for juveniles and $>3$ years for adults) was based upon the length of the animals (for harbour porpoises; T. Jauniaux, personal communication) and the development of their gonads (for harbour seals; T. Jauniaux, personal communication).

\subsection{Targeted compounds}

The following PBDE congeners (IUPAC numbers) were targeted for analysis: 28 $47,66,85,99,100,153,154,183$, and 209. BDE 77 was used as internal standard (IS) for tetra- and penta-BDE congeners, while BDE 128 was used as IS for hexa- and hepta-BDE congeners. For BDE 209, ${ }^{13} \mathrm{C}$-labelled BDE 209 was used as IS. The following 21 PCB congeners (IUPAC numbers) were targeted: 28, 31, 52, 74, 95, 99, $101,105,110,118,128,138,149,153,156,170,180,183,187,194$ and 199. Internal standards used were CB 46 and CB 143. Individual standards for PBDEs (Wellington Laboratories, Guelph, ON, Canada) and PCBs (Dr. Ehrenstorfer Laboratories, Augsburg, Germany) were used for identification and quantification.

\subsection{Chemicals}

All solvents used for the analysis ( $n$-hexane, acetone, dichloromethane, isooctane) were of pesticide-grade (Merck, Darmstadt, Germany). Sodium sulphate and silica were pre-washed with $n$-hexane before use. Extraction thimbles were preextracted for $1 \mathrm{~h}$ with the extraction mixture used for the samples and dried at $100{ }^{\circ} \mathrm{C}$ for $1 \mathrm{~h}$.

Table 1

Arithmetic means, standard deviations (SD) and range of biological data (length, weight and blubber thickness), concentrations of CB $153, \sum$ PCBs, BDE 47 and $\sum$ PBDEs ( $\mu \mathrm{g} / \mathrm{g}$ lipid weight) measured in blubber of harbour seals and harbour porpoises from the Southern North Sea.

\begin{tabular}{|c|c|c|c|c|c|c|c|c|}
\hline & \multicolumn{4}{|l|}{ Harbour seal } & \multicolumn{4}{|c|}{ Harbour porpoise } \\
\hline & AM & JM & $\mathrm{AF}$ & $\mathrm{JF}$ & AM & JM & $\mathrm{AF}$ & JF \\
\hline$n$ & 8 & 9 & 2 & 9 & 8 & 12 & 5 & 10 \\
\hline \multicolumn{9}{|l|}{ Length $(\mathrm{cm})$} \\
\hline Mean (SD) & $139.4(12.1)$ & $106.6(9.0)$ & $153.0(24.0)$ & $112.2(11.9)$ & $145.5(7.9)$ & $107.3(7.2)$ & $149.4(5.4)$ & $111.8(9.4)$ \\
\hline Range & $128-163$ & $93-120$ & $136-170$ & $94-130$ & $137-160$ & $96-117$ & $144-158$ & $94-127$ \\
\hline \multicolumn{9}{|l|}{ Weight ( $\mathrm{kg}$ ) } \\
\hline Mean (SD) & $46.6(8.9)$ & $23.3(5.1)$ & $69.5(41.7)$ & $25.0(8.5)$ & $41.6(7.1)$ & $19.2(4.9)$ & $47.6(10.0)$ & $22.8(4.9)$ \\
\hline Range & $34-58$ & $17-33$ & $40-99$ & $10-36$ & $36-58$ & $11.3-26.5$ & $36-60$ & $15-30$ \\
\hline Blubber thickness ( $\mathrm{mm}$ ) & $(n=6)$ & $(n=5)$ & $(n=1)$ & $(n=7)$ & & & & \\
\hline Mean (SD) & $20.5(9.5)$ & $14.6(6.6)$ & 50 & $10.9(2.8)$ & $9.1(5.1)$ & $10.8(9.6)$ & $15.6(6.9)$ & $14.2(5.9)$ \\
\hline Range & $11-35$ & $7-20$ & - & $6-15$ & $1.7-18$ & $4-40$ & $10-26$ & $3-22$ \\
\hline$n$ & 8 & $8^{a}$ & 2 & 8 & 8 & $11^{\mathrm{a}}$ & $4^{\mathrm{a}}$ & 10 \\
\hline \multicolumn{9}{|l|}{ СВ $153(\mu \mathrm{g} / \mathrm{g} l w)$} \\
\hline Mean (SD) & $28.9(23.3)$ & $7.2(2.4)$ & $4.3(4.3)$ & $10.3(10.8)$ & $28.7(12.0)$ & $3.9(3.0)$ & $1.7(0.6)$ & $3.7(4.1)$ \\
\hline Range & $0.8-65.9$ & $4.7-11.8$ & $1.3-7.3$ & $2.2-35.2$ & $11.6-46.0$ & $1.2-11.5$ & $1.0-2.3$ & $0.2-13.4$ \\
\hline \multicolumn{9}{|l|}{$\sum P C B s(\mu \mathrm{g} / \mathrm{g} l w)$} \\
\hline Mean (SD) & $72.4(58.2)$ & $20.7(6.7)$ & $12.5(12.2)$ & $28.3(27.6)$ & $82.9(31.8)$ & $15.4(10.7)$ & $7.3(2.0)$ & 12.9 (11.9) \\
\hline Range & $2.2-171.7$ & $12.7-33.8$ & $3.9-21.5$ & $6.5-91.5$ & $38.7-125.5$ & $5.3-39.8$ & $4.4-8.9$ & $1.3-39.3$ \\
\hline$n$ & 8 & 9 & 2 & 9 & 8 & 12 & 5 & $9^{a}$ \\
\hline \multicolumn{9}{|l|}{$B D E 47(\mu g / g l w)$} \\
\hline Mean (SD) & $0.21(0.11)$ & $0.35(0.21)$ & $0.12(0.05)$ & $0.42(0.31)$ & $0.69(0.46)$ & $1.11(1.16)$ & $0.43(0.30)$ & $0.45(0.27)$ \\
\hline Range & $0.07-0.40$ & $0.11-0.73$ & $0.08-0.15$ & $0.07-0.82$ & $0.11-1.43$ & $0.27-3.88$ & $0.15-0.79$ & $0.16-0.99$ \\
\hline \multicolumn{9}{|l|}{$\sum P B D E s(\mu g / g l w)$} \\
\hline Mean (SD) & $0.30(0.14)$ & $0.44(0.27)$ & $0.18(0.09)$ & $0.54(0.40)$ & $1.54(0.96)$ & $1.73(1.77)$ & $0.85(0.60)$ & $0.70(0.41)$ \\
\hline Range & $0.11-0.52$ & $0.13-0.87$ & $0.11-0.24$ & $0.09-1.15$ & $0.28-3.10$ & $0.50-5.93$ & $0.32-1.56$ & $0.22-1.48$ \\
\hline
\end{tabular}

J - juvenile ( $<3$ years); $A$ - adult ( $>3$ years); $F$ - female; $M$ - male.

a One outlier was excluded from the data set of the respective age-gender group. 


\subsection{Sample preparation and clean up}

The method used for the sample extraction and clean up has been previously described and validated (Covaci et al., 2002; Voorspoels et al., 2003), and is briefly presented below. Between 0.3 and $0.5 \mathrm{~g}$ blubber was dried with $\sim 8 \mathrm{~g}$ anhydrous $\mathrm{Na}_{2} \mathrm{SO}_{4}$, spiked with internal standards BDE 77/BDE 128 (25 ng), CB 46/CB 143 (75 ng) and ${ }^{13} \mathrm{C}-\mathrm{BDE} 209$ ( $7.5 \mathrm{ng}$ ) and extracted for $2 \mathrm{~h}$ by hot Soxhlet with $100 \mathrm{ml}$ hexane/ acetone $(3 / 1 ; \mathrm{v} / \mathrm{v})$. After lipid determination (performed on an aliquot of the extract), the extract was cleaned on $8 \mathrm{~g}$ of acidified silica. After elution of analytes with $15 \mathrm{ml}$ hexane and $10 \mathrm{ml}$ dichloromethane, the cleaned extract was concentrated to $200 \mu \mathrm{l}$.

\subsection{Analysis}

PBDEs were measured with an Agilent 6890-5973 gas chromatograph coupled with a mass spectrometer system (GC-MS). The GC was equipped with a $20 \mathrm{~m} \times 0.18 \mathrm{~mm} \times 0.20 \mu \mathrm{m}$ AT-5 capillary column (Alltech, Lokeren, Belgium) and the MS was operated in electron capture negative ionisation (ECNI) mode. Methane was used as reagent gas and the ion source, quadrupole and interface temperatures were set at 230,150 and $300^{\circ} \mathrm{C}$, respectively. The MS was used in the selected ionmonitoring (SIM) mode with ions $m / z=79$ and 81 (for tri- to hepta-BDEs) and $m /$ $z=484.7 / 486.7$ and 494.7/496.7 (for BDE 209 and ${ }^{13}$ C-BDE 209, respectively) monitored during the entire run. Dwell times were set at $40 \mathrm{~ms}$. One microlitre of the cleaned extract was injected in solvent vent mode (injector temperature: $90^{\circ} \mathrm{C}$, held for $0.05 \mathrm{~min}$, then with $700{ }^{\circ} \mathrm{C} / \mathrm{min}$ to $305^{\circ} \mathrm{C}$ and kept for $25 \mathrm{~min}$; vent flow was set at $75 \mathrm{ml} / \mathrm{min}$ and the purge vent opened at $1.5 \mathrm{~min}$ ). Helium was used as carrier gas at constant flow $(0.8 \mathrm{ml} / \mathrm{min})$. The temperature of the AT-5 column was kept at $90{ }^{\circ} \mathrm{C}$ for $1.50 \mathrm{~min}$, then increased to $200{ }^{\circ} \mathrm{C}$ at a rate of $20^{\circ} \mathrm{C} / \mathrm{min}$, further increased to $300{ }^{\circ} \mathrm{C}$ at a rate of $5^{\circ} \mathrm{C} / \mathrm{min}$, kept for $15 \mathrm{~min}$.

PCBs were measured with the same GC-MS system as for the PBDE determination, operated in electron ionisation (EI) mode and equipped with a $25 \mathrm{~m} \times 0.22 \mathrm{~mm} \times 0.25 \mu \mathrm{m}$ HT- 8 capillary column (SGE, Zulte, Belgium). The ion source, quadrupole and interface temperatures were set at 230,150 and $300^{\circ} \mathrm{C}$, respectively. The MS was used in the SIM mode with two ions monitored for each PCB homologue group. One microlitre of the cleaned extract was injected in cold pulsed splitless mode (injector temperature $90^{\circ} \mathrm{C}(0.03 \mathrm{~min})$ then to $300^{\circ} \mathrm{C}$ with $700{ }^{\circ} \mathrm{C} / \mathrm{min}$ ), pressure pulse $25 \mathrm{psi}$, pulse time $1.50 \mathrm{~min}$. The splitless time was $1.50 \mathrm{~min}$. Helium was used as carrier gas at constant flow $(1 \mathrm{ml} / \mathrm{min})$. The temperature of the HT- 8 column was kept at $90^{\circ} \mathrm{C}$ for $1.50 \mathrm{~min}$, then increased to $180^{\circ} \mathrm{C}$ at a rate of $15^{\circ} \mathrm{C} / \mathrm{min}$ (kept for $2.0 \mathrm{~min}$ ), further increased to $280^{\circ} \mathrm{C}$ at a rate of $5^{\circ} \mathrm{C} / \mathrm{min}$ and finally raised to $300{ }^{\circ} \mathrm{C}$ at a rate of $40{ }^{\circ} \mathrm{C} / \mathrm{min}$, kept for $12 \mathrm{~min}$.

\subsection{Quality assurance/quality control (QA/QC)}

Multi-level calibration curves were created for the quantification and good correlation $\left(r^{2}>0.999\right)$ was achieved. The identification of each target analyte was based on their relative retention times (RRTs) to the internal standard used for quantification, ion chromatograms and intensity ratios of the monitored ions. A deviation of the ion intensity ratios within $20 \%$ of the mean values of the calibration standards was considered acceptable. Recoveries for individual PBDE congeners were between 87 and $104 \%$ (RSD $<12 \%$ ), while recoveries of PCBs ranged between 75 and $90 \%(\mathrm{RSD}<10 \%$ ).

For each analyte, the mean procedural blank value was used for subtraction. After blank subtraction, the limit of quantification (LOQ) was set at three times the standard deviation of the procedural blank, which ensures $>99 \%$ certainty that the reported value is originating from the sample. For analytes that were not detected in procedural blanks, LOQs were calculated for a signal-to-noise ratio equal to 10. LOQs depended on the sample intake and on the analyte and ranged between 1 and $4 \mathrm{ng} / \mathrm{g}$ lipid weight (lw).

OC was performed by regular analyses of procedural blanks, by random injection of standards and solvent blanks. A standard reference material SRM 1945 (PCBs and PBDEs in whale blubber) was used to test the method accuracy. Obtained values were not deviating more than $10 \%$ from the certified values. The OC scheme is also assessed through regular participation to interlaboratory comparison exercises organised by the Arctic Monitoring Assessment Programme and the National Institute of Standards and Technology.

\subsection{Statistical analysis}

Statistical analyses were conducted using the SPSS 14.0 statistical package. The level of statistical significance was defined at $p<0.05$. Outliers in all groups, detected using Grubbs' test, were removed before further calculations. Differences in the concentrations and profiles of PCBs and PBDEs were compared between the groups (adult males, adult females, juvenile males and juvenile females) using one-way ANOVA, followed by Tukey's post hoc test. Correlation coefficients between PCBs and PBDEs were calculated using GraphPad Prism 4 (GraphPad Software, Inc.).

\section{Results and discussion}

\section{1. $P C B$ concentrations}

Of the 21 congeners analyzed, only congener $\mathrm{CB} 31$ was detected in less than $50 \%$ of the blubber samples from harbour seals and porpoises and therefore this congener was removed from the following statistical interpretation. The remaining PCBs were measured in all samples. PCB concentrations (sum of 21 congeners) in blubber tissue ranged between $2.2-172 \mu \mathrm{g} / \mathrm{g}$ lw and $1.3-126 \mu \mathrm{g} / \mathrm{g}$ lw for harbour seals and porpoises, respectively. These minimum and maximum values represent a large range, underlying the numerous biotic factors involved in PCB lipid accumulation (e.g. age, gender and body condition). Therefore, the samples from both species were divided into four groups according to their age and gender: adult male (AM), adult female (AF), juvenile male (JM) and juvenile female (JF). The results for the $\sum$ PCBs for harbour seals and porpoises are given in Table 1. Results for CB 153, the most persistent $\mathrm{PCB}$ congener in marine mammals are also shown in Table 1 to allow comparisons with other studies. Almost all conclusions drawn for the $\sum$ PCBs were similar for CB 153 (although with other $F$ and $p$-values).

For both species, the AM group contained the highest PCB concentrations probably due to bioaccumulation of these contaminants in time. Contrarily, the AF group displayed the lowest concentrations linked to the well-described transfer during gestation and lactation (Covaci et al., 2002; Wolkers et al., 2004; Shaw et al., 2005). PCB concentrations were similar between JM and JF $(p>0.05)$ suggesting that the accumulation pattern is comparable between males and females until sexual maturity.

Harbour porpoises from the AM group tend to have higher, although not statistically significant, concentrations of $\sum$ PCBs than harbour seals $\left(F_{1,14}=0.200 ; p=0.662\right)$, while the concentrations in the other groups (JM, JF and AF) were lower compared with the corresponding group of the harbour seals $\left(F_{1,17}=1.520 ; p=0.234\right.$ for JM, $F_{1,16}=2.539 ; p=0.131$ for JF and $F_{1,4}=0.907 ; p=0.395$ for $\mathrm{AF}$, respectively). An explanation can be found in differences in age, body size or in the blubber thickness. Differences in the concentrations of PCBs between the outer and inner blubber layers, with the outer layers having significantly higher concentrations, have been reported previously in grey seals (Halichoerus grypus) (Debier et al., 2003a), in harp seals (Phoca groenlandica) (Lydersen et al., 2002), in ringed seals (Phoca hispida) (Severinsen et al., 2000) and in bottlenose dolphins (Tursiops truncatus) (Montie et al., 2008). The mean blubber thickness in the AM group was $9.1 \mathrm{~mm}$ for harbour porpoises and $20.5 \mathrm{~mm}$ for harbour seals. Therefore, the probability of having samples from the outer blubber layer is greater for porpoises than for seals, with an overestimation of the reported $\mathrm{PCB}$ concentrations as a consequence (Fig. 1A). The difference in the body size, which influences the food intake and therefore the contaminant uptake, could be another possible explanation for variation between species (reviewed by Borgå et al., 2004). However, in the present study, no influence of body size could be detected, because there were no significant differences in body size between the same age groups of both species (all $p>0.1$ ).

Due to the number and position of chlorine atoms, PCB congeners do not follow the same metabolic pathways which result in the formation of different metabolites (Letcher et al., 2000) and in differences in accumulation patterns and persistence of PCBs. This has resulted in the classification of PCBs in several groups as introduced by Bruhn et al. (1995) and Boon et al., 1997 and recently further developed by Wolkers et al. (2007) (Table 2). The most persistent congeners from the metabolic groups I and IIIB reached the highest proportions in harbour seals and porpoises, with percentages between $90-95 \%$ and $67-81 \%$, respectively (Fig. 2). Less persistent congeners (metabolic groups IIB, IIC and IIIA) had higher contributions in the blubber of harbour porpoises (especially CB 149), but were less important in harbour seals.

Concentrations of CB 153 were higher in the present study than in similar species from other seas and oceans, indicating that the Southern part of the North Sea is still highly contaminated with PCBs, in agreement with previous published studies. Reijnders 

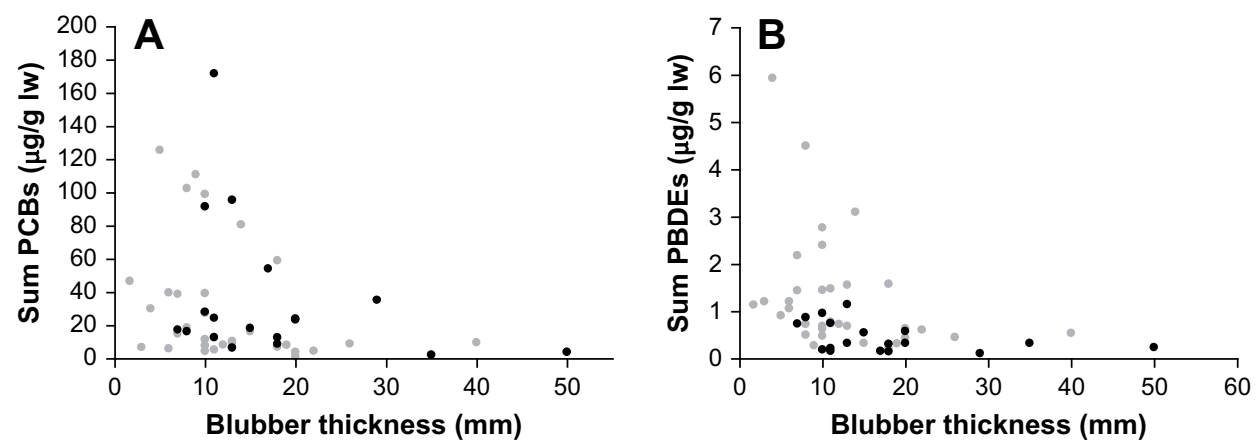

Fig. 1. Relationship between the blubber thickness $(\mathrm{mm})$ and $(\mathrm{A})$ the $\sum \mathrm{PCB}$ concentrations $(\mu \mathrm{g} / \mathrm{g} \mathrm{lw})$ and $(\mathrm{B})$ the $\sum \mathrm{PBDE}$ concentrations $(\mu \mathrm{g} / \mathrm{g}$ lw) in blubber of harbour porpoises (O) and harbour seals (

(1986) measured high PCB levels causing reproductive failures in harbour seals from the Wadden Sea. Vetter et al. (1996) found the highest PCB levels in harbour seals from the Dutch Wadden Sea and concluded that this area is the major source of input of PCBs into the North Sea and North Atlantic. The same study also found decreasing PCB levels along the continental line from the North Sea to Germany, Denmark and Norway (Table 3). Similar trends have been observed in harbour porpoise with decreasing PCB and PBDE concentrations from German Baltic and North Sea to Iceland (Das et al., 2006). Covaci et al. (2002) also found that concentrations of PCBs in harbour porpoises from the Southern North Sea were higher than in porpoises from the English or Scottish coast of the North Sea.

\subsection{General PCB profiles}

CB 153 was the dominant PCB congener in all individuals of both marine mammal species. Profiles for harbour seals (CB $153>$ CB $138>\mathrm{CB} 187>\mathrm{CB} 180>\mathrm{CB}$ 99) and harbour porpoises ( $\mathrm{CB}$ $153>$ CB $138>$ CB $149>$ CB $187>$ CB 180) were similar for all age groups, except for $A F$ porpoises (Fig. $3 A$ and $B$ ). These results confirm the PCB profiles reported in the literature and reflect the differences in the accumulation of certain PCB congeners (e.g. CB 101 and CB 149) between pinnipeds (seals) and cetaceans (porpoises) (Hutchinson and Simmonds, 1994; Vetter et al., 1996; Boon et al., 1997).

Ratios between the concentrations of individual PCB congeners and concentration of $C B 153$ for each animal within the four agegender groups were used to construct relative PCB profiles in order to be able to make comparisons between the two species:

$R_{153}\left(\mathrm{CB}_{X}\right)=\frac{\left[\mathrm{CB}_{x}\right]}{\left[\mathrm{CB}_{153}\right]}$

Table 2

Classification of the PCB congeners analyzed in the present study according to Bruhn et al. (1995), Boon et al. (1997) and Wolkers et al. (2007).

\begin{tabular}{|c|c|c|c|}
\hline $\begin{array}{l}\text { Metabolic } \\
\text { group }\end{array}$ & Description & $\begin{array}{l}\text { Cytochrome P450 } \\
\text { induction }\end{array}$ & $\begin{array}{l}\text { PCB congeners in the } \\
\text { present study }\end{array}$ \\
\hline $\bar{I}$ & $\begin{array}{l}\text { No vicinal } o, m \text { or } \\
m, p \text { H-atoms }\end{array}$ & $2 \mathrm{~B}^{\mathrm{a}}$ & $\begin{array}{l}153,180,183,187, \\
194,199\end{array}$ \\
\hline IIA & $\begin{array}{l}\text { Vicinal } m, p \text { H-atoms } \\
\text { and } \leq 1 o \text {-Cls }\end{array}$ & $\begin{array}{l}2 \mathrm{~B} / 3 \mathrm{~A} \text { and } 1 \mathrm{~A} \\
(\text { maximum } 10-\mathrm{Cl})\end{array}$ & None \\
\hline IIB & $\begin{array}{l}\text { Vicinal } m, p \text { H-atoms } \\
\text { and } 2 o \text {-Cls }\end{array}$ & & $52,101,110$ \\
\hline IIC & $\begin{array}{l}\text { Vicinal } m, p \text { H-atoms } \\
\text { and } 3 o \text {-Cls }\end{array}$ & & 95,149 \\
\hline IIIA & $\begin{array}{l}\text { No vicinal } m, p \\
\mathrm{H} \text {-atoms and } \\
\leq 1 \quad-\mathrm{Cl}\end{array}$ & $1 \mathrm{~A}$ and $2 \mathrm{~B}^{\mathrm{a}}$ & $\begin{array}{l}28,31,74,105,118 \\
156\end{array}$ \\
\hline IIIB & $\begin{array}{l}\text { No vicinal } m, p \\
\mathrm{H} \text {-atoms and } \geq 2 o \text {-Cls }\end{array}$ & $2 \mathrm{~B} / 1 \mathrm{~A}^{\mathrm{a}}$ & $99,128,138,170$ \\
\hline
\end{tabular}

a Boon et al. (1997), o - ortho, $m$ - meta, $p$ - para.
For harbour seals, the JM, JF and AF groups showed similar and higher ratios for all PCBs than the AM group (Fig. 3A), suggesting a better-developed metabolic capacity with age or an increased metabolism with higher blubber concentrations for adult males.

For harbour porpoises, a higher contribution of higher chlorinated congeners, such as CB 170, CB 180, CB 183, CB 187, CB 194 and CB 199, was observed for the AF group (Fig. 3B). This might be the result of a selective transport of lower chlorinated PCB congeners to their offspring and, as a consequence, an enrichment of the higher chlorinated PCB congeners in the blubber of AF individuals. Similar to our observations, Debier et al. (2003b) reported higher contributions of higher chlorinated PCBs in blubber of adult female grey seals and higher proportions of lower chlorinated PCBs in milk. The same study also assumed a higher contribution of lower chlorinated PCBs in blubber of pups. Indeed, juvenile porpoises from our study had higher ratios for lower chlorinated congeners ( $C B 28, C B$ 52, CB 74, CB 95, CB 99, CB 101, CB 118, CB 110 and CB 105), probably due to their limited capacity for metabolic breakdown and as a result of selective transfer of PCB lower chlorinated congeners during lactation. For all congeners, the AM group showed the lowest ratios in harbour porpoises suggesting a better-developed capacity for PCB metabolism for this group.

Compared to harbour seals, harbour porpoises had a higher proportion of lower chlorinated (less persistent) congeners, such as CB 52, CB 95, CB 101, CB 118 and CB 149. In both species, persistent PCB congeners (CB 138, CB 170, CB 180 and CB 187) had a similar contribution. All together, this means that harbour seals are able to metabolize lower chlorinated PCB congeners in a more efficient way than harbour porpoises. This finding, namely a distinction

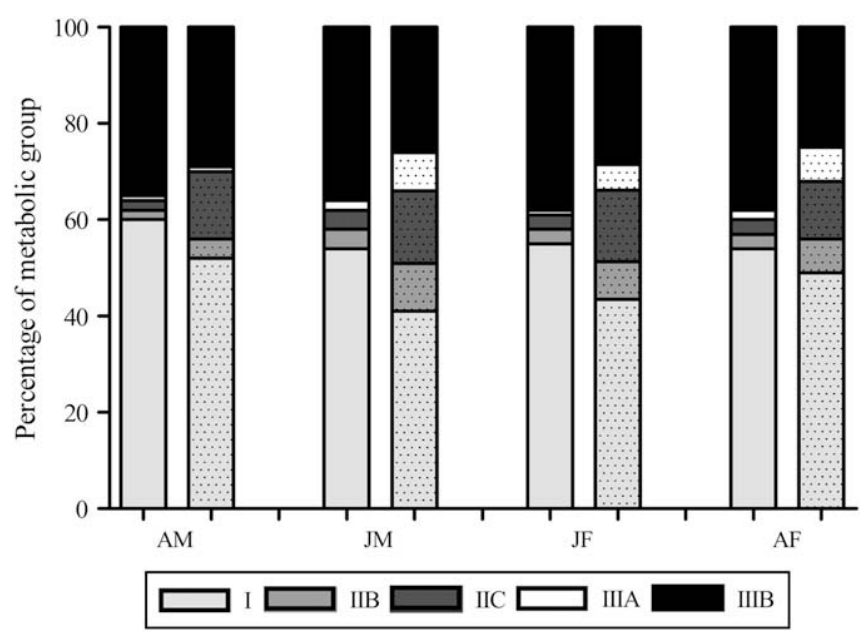

Fig. 2. Percentages of the metabolic groups (see Table 2) in the four age-gender groups of harbour seals (columns without dots) and porpoises (columns with dots). 
Table 3

Mean concentrations and standard deviations (between brackets) in $\mu \mathrm{g} / \mathrm{g}$ lipid weight of CB 153 in blubber tissue of harbour seals and porpoises.

\begin{tabular}{|c|c|c|c|c|c|c|c|c|}
\hline \multirow[t]{2}{*}{ Species } & \multirow[t]{2}{*}{ Location } & \multirow[t]{2}{*}{ Year } & \multirow[t]{2}{*}{$n$} & \multicolumn{4}{|c|}{ CB 153 ( $\mu \mathrm{g} / \mathrm{g}$ lipid weight) } & \multirow[t]{2}{*}{ Reference } \\
\hline & & & & AM & JM & $\mathrm{AF}$ & $\mathrm{JF}$ & \\
\hline \multirow[t]{3}{*}{ Harbour seal } & Canada & $1996-2000$ & 8 & $10.6(5.1)$ & & & & Hobbs et al., 2002 \\
\hline & Norway & & $6-4$ & 0.61 & & 0.12 & & Wolkers et al., 2004 \\
\hline & Southern North Sea & 1999-2004 & $8-8-2-8$ & $28.9(23.3)$ & $7.2(2.4)$ & $4.3(4.3)$ & $10.3(10.8)$ & Present study \\
\hline \multirow[t]{6}{*}{ Harbour porpoise } & Baltic Sea & 1985-1993 & $4-13$ & $20(13)$ & $6.6(3.6)$ & & & Berggrena et al., 1999 \\
\hline & Kattegat-Skagerrak & 1988-1990 & $7-10$ & $5.7(2.3)$ & $4.8(2.5)$ & & & Berggrena et al., 1999 \\
\hline & & 1978-1981 & 5 & $19(12)$ & & & & Berggrena et al., 1999 \\
\hline & Norway & $1988-1990$ & 8 & $5.6(4.6)$ & & & & Berggrena et al., 1999 \\
\hline & United Kingdom & 1999-2004 & $16-18-8-15$ & $3.7(3.2)$ & $4.4(7.4)$ & $2.2(1.5)$ & $2.9(1.6)$ & Law et al., 2006b \\
\hline & Southern North Sea & 1999-2004 & $8-11-4-10$ & $28.7(12.0)$ & $3.9(3.0)$ & $1.7(0.6)$ & $3.7(4.1)$ & Present study \\
\hline
\end{tabular}

between lower and higher chlorinated compounds for harbour seals, agrees with findings of Boon et al. (1997) and Hobbs et al. (2002).

\subsection{PBDE concentrations}

Of the 10 congeners analyzed, congeners BDE 85 and BDE 183 were detected in less than $50 \%$ of the blubber samples from both harbour seals and porpoises. BDE 66 was measured in all samples from harbour porpoises, but in less than $50 \%$ of harbour seals. BDE 209 could not be detected in any investigated sample at concentrations higher than $10 \mathrm{ng} / \mathrm{g}$ lw (LOQ). This agrees with previous reports which could not detect BDE 209 in marine mammals (Boon et al., 2002) or which have infrequently measured BDE 209 at concentrations between 1 and $8 \mathrm{ng} / \mathrm{g}$ lw in seals (Thomas et al., 2005; Shaw et al., 2007). Since very low or not detectable concentrations of BDE 209 were found in fish species which are prey for the two studied marine mammal species (Voorspoels et al., 2003) and the half-life of BDE 209 in blood of grey seals was estimated between 8.5 and 13 days (Thomas et al., 2005), it is plausible to assume that BDE 209 does not bioaccumulate in aquatic biota. However, this congener is of particular concern, because it debrominates (in fish) to lower brominated PBDE congeners (such as BDE 154 and BDE 155), which are more water soluble and probably more persistent in biota (Stapleton et al., 2004). The remaining congeners were measured in all samples from both species. Results for $\sum$ PBDEs and BDE 47, the most persistent PBDE congener in marine mammals, are given in Table 1 . Statistical comparisons for $\sum$ PBDEs and BDE 47 were similar, although with different $F$ and $p$-values.

The highest concentrations of $\sum$ PBDEs for all age-gender groups were observed in harbour porpoises (range $0.22-5.93 \mu \mathrm{g} / \mathrm{g} \mathrm{lw}$ ) compared with harbour seals (range $0.09-1.15 \mu \mathrm{g} / \mathrm{g}$ lw) (Table 1).
For harbour porpoises, males were more contaminated than females $\left(F_{1,32}=4.942 ; p=0.033\right)$ with the JM group having the highest $(1.73 \pm 1.77 \mu \mathrm{g} / \mathrm{g} \mathrm{lw})$ and the group JF the lowest $(0.70 \pm 0.41 \mu \mathrm{g} / \mathrm{g} \mathrm{lw})$ mean concentrations. For harbour seals, juveniles tended to have higher $\sum$ PBDE concentrations than adults suggesting that the capacity for metabolic breakdown increases with age or with higher body burdens. Yet these findings were not statistically significant. This finding contrasts with the higher concentrations measured in adult (age $>5$ years) ringed seals compared to subadult specimens (age $<5$ years) from East Greenland (Vorkamp et al., 2004), but agrees with results from harbour seals from UK waters (Law et al., 2006b; MAFF, 1994) (Table 4).

Similar to PCBs, PBDE concentrations in the AF group were lower than the other age-gender groups, supporting the hypothesis that adult female animals reduce their contaminant loads through gestation and lactation (Covaci et al., 2002; Law et al., 2002).

Similar to PCBs (see above), a decrease in the PBDE concentrations was observed with the increase in the blubber thickness of harbour porpoises, but not of harbour seals (Fig. 1B). This, together with the fact that the blubber thickness was lower for harbour porpoises, suggests that the probability of having samples from the outer blubber layer was greater for porpoises than for seals. As a consequence, a higher frequency of high PBDE concentrations was observed for low blubber thickness values (Fig. 1B).

The PBDE concentrations measured in the present study are similar or slightly higher than in other studies, though information about PBDEs in marine mammals (reviewed by Law et al., 2003, 2006a; Das et al., 2006) is scarce compared to PCBs (Table 4). Kajiwara et al. (2006) investigated PBDEs in several small male cetaceans from Asian waters and reported concentrations between $0.006 \mu \mathrm{g} / \mathrm{g} \mathrm{lw}$ in blubber of spinner dolphins (Stenella longirostris) from India (between 1990 and 1992) and $6 \mu \mathrm{g} / \mathrm{g}$ lw in Indo-Pacific
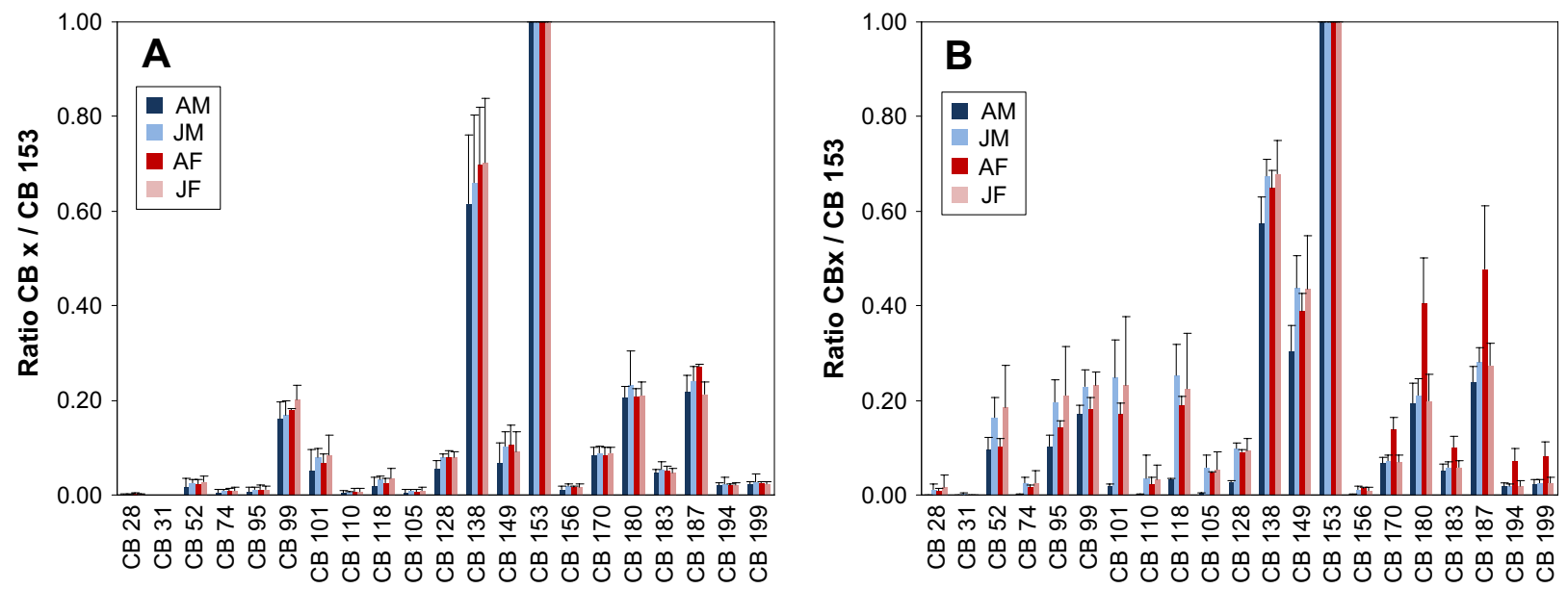

Fig. 3. Ratios between mean concentrations of each individual $\mathrm{PCB}$ congener and $\mathrm{CB} 153\left(R_{153}\left(\mathrm{CB}_{x}\right)\right)$ in harbour seals $(\mathrm{A})$ and harbour porpoises (B). Error bars represent $\mathrm{SD}$. 
Table 4

Mean concentrations and standard deviations (between brackets) in $\mu \mathrm{g} / \mathrm{g}$ lipid weight of BDE 47 in blubber tissue of harbour seals and porpoises.

\begin{tabular}{|c|c|c|c|c|c|c|c|c|}
\hline \multirow[t]{2}{*}{ Species } & \multirow[t]{2}{*}{ Location } & \multirow[t]{2}{*}{ Year } & \multirow[t]{2}{*}{$n$} & \multicolumn{4}{|c|}{ BDE 47 ( $\mu \mathrm{g} / \mathrm{g}$ lipid weight) } & \multirow[t]{2}{*}{ Reference } \\
\hline & & & & AM & JM & $\mathrm{AF}$ & $\mathrm{JF}$ & \\
\hline \multirow[t]{3}{*}{ Harbour seal } & California & 1989-1998 & $6-4$ & $2.04(2.41)$ & & $0.20(0.15)$ & & She et al., 2002 \\
\hline & North Sea & & 9 & \multicolumn{4}{|c|}{1.24} & Boon et al., 2002 \\
\hline & Southern North Sea & 1999-2004 & $8-9-2-9$ & $0.21(0.11)$ & $0.35(0.21)$ & $0.12(0.05)$ & $0.42(0.31)$ & Present study \\
\hline \multirow[t]{3}{*}{ Harbour porpoise } & North Sea & & 9 & \multicolumn{4}{|c|}{0.86} & Boon et al., 2002 \\
\hline & United Kingdom & 1992-2004 & $31-31-24-22$ & $0.52(0.53)$ & $1.02(1.23)$ & $0.74(1.07)$ & $1.23(1.21)$ & MAFF, 1994; Law et al., 2006b \\
\hline & Southern North Sea & 1999-2004 & $8-12-5-9$ & $0.69(0.46)$ & $1.11(1.16)$ & $0.43(0.30)$ & $0.45(0.27)$ & Present study \\
\hline
\end{tabular}

humpback dolphins (Sousa chinensis) from Hong Kong (between 1997 and 2001). The same study found PBDE concentrations (sum of 10 congeners) ranging from 0.024 to $0.100 \mu \mathrm{g} / \mathrm{g} \mathrm{lw}$ in male harbour porpoises $(n=3)$ from Japan. Despite the small sample size, these results are an order of magnitude lower than these for harbour porpoises from the present study. Shaw et al. (2007) reported mean PBDE concentrations in blubber tissue of harbour seals stranded in the North-Western Atlantic between 1991 and 2005 and found concentrations almost 10 times higher as in present study (3.65 $\mu \mathrm{g} / \mathrm{g}$ lw for harbour seal pups $(n=13), 2.94 \mu \mathrm{g} / \mathrm{g}$ lw for juveniles $(n=14), 1.39 \mu \mathrm{g} / \mathrm{g}$ lw for AM $(n=7)$ and $0.33 \mu \mathrm{g} / \mathrm{g}$ lw for $\mathrm{AF}(n=8)$ ). This is probably a reflection of the higher usage of the penta-BDE technical mixture in North America compared to Europe (Law et al., 2003).

\subsection{General PBDE profiles}

BDE 47 was the most abundant congener in all analyzed samples of both species similar to previous findings for the same species (Boon et al., 2002; Covaci et al., 2002; Shaw et al., 2007) and other marine mammals (sperm whales Physeter macrocephalus, de Boer et al., 1998; ringed seals and beluga whales Delphinapterus leucas, Wolkers et al., 2004; bottlenose dolphins, Johnson-Restrepo et al., 2005; Californian sea lions Zalophus californianus, Stapleton et al., 2006).

Profiles for JF and JM harbour porpoise were similar, namely BDE $47>\operatorname{BDE} 100>$ BDE $99>$ BDE $154>$ BDE 153. For AF and AM harbour porpoises, this pattern changed into $\mathrm{BDE} 47>\mathrm{BDE}$ $99>$ BDE $100>$ BDE $154>$ BDE 153. These profiles are comparable with results from Boon et al. (2002) for harbour porpoises, but differ from bottlenose dolphins (Johnson-Restrepo et al., 2005).

Profiles for harbour seals are different, with the AM harbour seal showing the following pattern, BDE $47>$ BDE $153>$ BDE 99, BDE $154>$ BDE 100. The profiles for other age-gender groups are different from that of the AM group BDE $47>$ BDE $99>$ BDE
$100 \sim$ BDE $153>$ BDE 154. Similar results were also found by Shaw et al. (2007).

Ratios between the concentrations of individual PBDE congeners and the concentration of BDE 47, the most persistent and dominant PBDE, for each animal within the four age-gender groups were used to construct relative PBDE profiles for harbour seals and porpoises (Fig. 4A and B):

$R_{47}\left(\mathrm{BDE}_{\chi}\right)=\frac{\left[\mathrm{BDE}_{\chi}\right]}{\left[\mathrm{BDE}_{47}\right]}$

For harbour seals (Fig. 4A), the JM and JF groups showed lower proportions of all measured PBDEs, while the AM and AF groups had slightly higher contributions of BDE 99, BDE 100, BDE 153 and BDE 154, combined with lower concentrations of this congeners, which is a reflection of the higher concentrations of BDE 47 in juveniles compared to adults.

For harbour porpoises (Fig. 4B), the same trends as found for harbour seals were observed. Juveniles seemed to have lower contributions of all measured PBDE congeners than adults, probably because of a higher 'start concentration' of BDE 47 from lactation and gestation (assuming that similar to PCBs, the less lipophilic congeners will be mostly abundant in milk), together with a minimal metabolism at that age. In general, harbour porpoises had a higher contribution of congeners BDE 99, BDE 100, BDE 153 and BDE 154 compared to harbour seals. Although congeners BDE 28, BDE 66 and BDE 183 were infrequently detected, their concentrations were higher in porpoises than in seals, indicating that harbour porpoises have difficulties with metabolizing PBDEs.

\subsection{Relationship between PCBs and PBDEs}

Johnson-Restrepo et al. (2005) reported a significant correlation $(r=0.83, p<0.01)$ between PCB and PBDE concentrations in fish and a higher correlation coefficient for the relationship between


Fig. 4. Ratios between mean concentrations of each individual PBDE congener and BDE $47\left(R_{47}\left(\mathrm{BDE}_{x}\right)\right)$ in harbour seals $(\mathrm{A})$ and harbour porpoises (B). Error bars represent standard deviations. 
PCBs and PBDEs in dolphins and sharks from coastal Florida. Shaw et al. (2007) found a highly significant correlation $(r=0.82$, $p<0.01$ ) between PCBs and PBDEs in harbour seals from the NorthWestern Atlantic coast. In the present study, no significant correlations between PCBs and PBDEs or between CB 153 and BDE 47 in harbour seals or harbour porpoises could be found (all $p>0.05$ ), all age groups together or separate. This could be an indication for a different accumulation and biomagnification through the food chain, but it may also reflect the variation in accumulation within each age-gender group.

\subsection{Adverse effects}

The PCB and PBDE concentrations, found in the present study, can be a serious threat for harbour seals and porpoises. Mean concentrations for PCBs and PBDEs in harbour porpoises in the present study (Table 1) are more than 2 (for AF) to 20 (for AM) times higher for PCBs and about 10 times higher for PBDEs compared to concentrations from stranded or bycaught harbour porpoises from European coasts which are associated with interfollicular fibrosis, splenic depletion and thymic atrophy (Beineke et al., 2005; Das et al., 2006). Furthermore, PCB concentrations in almost all agegender groups of both species are more than an order of magnitude higher than levels of PCBs negatively associated with vitamin A (a dietary hormone essential to growth, development, reproduction and immune function) concentrations in plasma and blubber of free-ranging harbour seals from British Columbia (Canada) and Washington State (USA) (Mos et al., 2007).

\section{Conclusions}

Harbour porpoises and harbour seals, two representative top predator species for the North Sea ecosystem, are good indicators of coastal pollution, because they have long life spans, feed high in the food chain and do not present large-scale migration. We found that factors, such as age and gender, among others, are important for the bioaccumulation of PCBs and PBDEs in marine mammals. The AM group had the highest concentrations of PCBs, but not of PBDEs, probably because of an increased metabolism with age or body burden. The AF group could eliminate considerable amounts of PCBs and PBDEs by gestation and lactation resulting in low concentrations. However, the transfer of PBDEs to the offspring needs more attention in the future. Juvenile animals had mixed trends in concentrations with the lowest concentrations for PCBs, but the highest for PBDEs. Harbour seals, members of the pinnipeds, and harbour porpoises, members of the Cetacea, are from an evolutionary point of view different and have therefore a different ability for metabolic breakdown reflected by the different PCB or PBDE profiles. Harbour porpoises have more difficulties of metabolizing lower halogenated and less persistent $\mathrm{PCB}$ and $\mathrm{PBDE}$ congeners than harbour seals probably due to less efficient cytochrome P450 enzymes. This could lead to bioaccumulation of these contaminants to a greater extent in harbour porpoises and subsequently to possible adverse effects.

\section{Acknowledgements}

Thierry Jauniaux (University of Liège, Belgium) and Ursula Siebert (Forschungs- und Technologiezentrum Westküste, University of Kiel, Germany) are greatly acknowledged for performing the necropsy of the stranded animals. Liesbeth Weijs acknowledges financial support from the Institute for the Promotion of Innovation through Science and Technology in Flanders (IWT-Vlaanderen). Adrian Covaci is financially supported by a postdoctoral fellowship from the Research Scientific Foundation - Flanders (FWO). Krishna
Das is financially supported by the FNRS (Fonds pour la Recherche Scientifique).

\section{References}

AMAP, 2004. AMAP Assessment 2002: Persistent Organic Pollutants (POPs) in the Arctic. Arctic Monitoring and Assessment Programme (AMAP), Oslo, Norway, $310 \mathrm{pp}$.

Beineke, A., Siebert, U., McLachlan, M., Bruhn, R., Thron, C., Failing, K., Müller, G., Baumgärtner, W., 2005. Investigations of the potential influence of environmental contaminants on the thymus and spleen of harbour porpoises (Phocoena phocoena). Environmental Science and Technology 39, 3933-3938.

Berggrena, P., Ishaq, R., Zebühr, Y., Näf, C., Bandh, C., Broman, D., 1999. Patterns and levels of organochlorines (DDTs, PCBs, non-ortho PCBs and PCDD/Fs) in male harbour porpoises (Phocoena phocoena) from the Baltic Sea, the Kattegat-Skagerrak Seas and the West Coast of Norway. Marine Pollution Bulletin 38, 1070-1084.

Birnbaum, L.S., Staskal, D.F., 2004. Brominated flame retardants: cause for concern? Environmental Health Perspectives 112, 9-17.

de Boer, J., Wester, P.G., Klamer, H.J.C., Lewis, W.E., Boon, J.P., 1998. Do flame retardants threaten ocean life? Nature 394, 28-29.

de Boer, J., de Boer, K., Boon, J.P., 2000. Polybrominated biphenyls and diphenylethers. In: Paasivirta, J. (Ed.), The Handbook of Environmental Chemistry, Vol. 3, Part K, New Types of Persistent Halogenated Compounds. Springer-Verlag, Berlin Heidelberg.

Boon, J.P., van der Meer, J., Allchin, C.R., Law, R.J., Klungsoyr, J., Leonards, P.E.G., Spliid, H., Storr-Hansen, E., Mckenzie, C., Wells, D.E., 1997. Concentrationdependent changes of PCB patterns in fish-eating mammals: structural evidence for induction of cytochrome P450. Archives of Environmental Contamination and Toxicology 33, 298-311.

Boon, J.P., Lewis, W.E., Tjoen-A-Choy, M.R., Allchin, C.R., Law, R.J., de Boer, J., Ten Hallers-Tjabbes, C.C., Zegers, B.N., 2002. Levels of polybrominated diphenyl ether (PBDE) flame retardants in animals representing different trophic levels of the North Sea food web. Environmental Science and Technology 36, 4025-4032.

Borgå, K., Fisk, A.T., Hoekstra, P.F., Muir, D.C.G., 2004. Biological and chemical factors of importance in the bioaccumulation and trophic transfer of persistent organochlorine contaminants in Arctic marine food webs. Environmental Toxicology and Chemistry 23, 2367-2385.

Bruhn, R., Kannan, N., Petrick, G., Schulz-Bull, D.E., Duinker, J.C., 1995. CB pattern in the harbour porpoise: bioaccumulation, metabolism and evidence for cytochrome P450 IIB activity. Chemosphere 31, 3721-3732.

Covaci, A., Van de Vijver, I., De Coen, W., Das, K., Bouquegneau, J.M., Blust, R., Schepens, P., 2002. Determination of organohalogenated contaminants in liver of harbour porpoises stranded on the Belgian North Sea coast. Marine Pollution Bulletin 44, 1156-1164.

Damstra, T., Barlow, S., Bergman, A., Kavlock, R., Van der Kraak, G., 2002. Global Assessment of the State-of-the-Science of Endocrine Disruptors. WHO publication no. WHO/PCS/EDC/02.2. World Health Organization, Geneva, Switzerland. http://www.who.int/ipcs/publications/endocrine_disruptors/en/.

Das, K., Siebert, U., Fontaine, M., Jauniaux, T., Holsbeek, L., Bouquegneau, J.M., 2004. Ecological and pathological factors related to trace metal concentrations in harbour porpoises Phocoena phocoena from the North Sea and adjacent areas. Marine Ecology Progress Series 281, 283-295.

Das, K., Vossen, A., Tolley, K., Vikingsson, G., Thron, K., Baumgärtner, W., Siebert, U., 2006. Interfollicular fibrosis in the thyroid of the harbour porpoise: an endocrine disruption? Archives of Environmental Contamination and Toxicology 52, 720-729.

Debier, C., Pomeroy, P.P., Dupont, C., Joiris, C., Comblin, V., Le Boulengé, E., Larondelle, Y., Thomé, J.P., 2003a. Quantitative dynamics of PCB transfer from mother to pup during lactation in UK grey seals Halichoerus grypus. Marine Ecology Progress Series 247, 237-248.

Debier, C., Pomeroy, P.P., Dupont, C., Joiris, C., Comblin, V., Le Boulengé, E., Larondelle, Y., Thomé, J.P., 2003b. Dynamics of PCB transfer from mother to pup during lactation in UK grey seals Halichoerus grypus: differences in PCB profile between compartments of transfer and changes during the lactation period. Marine Ecology Progress Series 247, 249-256.

Directive 2002/95/EC of the European Parliament and of the Council of 27 January 2003 on the restriction of the use of certain hazardous substances in electrical and electronic equipment. Official Journal L 037, 13/02/2003, 19-23.

Duinker, J.C., Hillebrand, M.T.J., 1979. Mobilization of organochlorines from female lipid tissue and transplacental transfer to fetus in a harbour porpoise (Phocoena phocoena) in a contaminated area. Bulletin of Environmental Contamination and Toxicology 23, 728-732.

Duinker, J.C., Hillebrand, M.T.J., Zeinstra, T., Boon, J.P., 1989. Individual chlorinated biphenyls and pesticides in tissues of some cetacean species from the North Sea and the Atlantic Ocean: tissue distribution and biotransformation. Aquatic Mammals 15, 95-124.

Dunkin, R.C., McLellan, W.A. Blum, J.E, Pabst, D.A, 2005. The ontogenetic changes in the thermal properties of blubber from Atlantic bottlenose dolphin (Tursiops truncates). The Journal of Experimental Biology 208, 1469-1480.

Fair, P.A., Becker, P.R., 2000. Review of stress in marine mammals. Journal of Aquatic Ecosystem Stress and Recovery 7, 335-354.

Fontaine, M.C., Tolley, K.A., Siebert, U., Gobert, S., Lepoint, G., Bouquegneau, J.M., Das, K., 2007. Long-term feeding ecology and habitat use in harbour porpoises 
Phocoena phocoena from Scandinavian waters inferred from trace elements and stable isotopes. BMC Ecology 7, 1-12.

Gauthier, J.M., Dubeau, H., Rassart, E., Jarman, W.M., Wells, R.S., 1999. Biomarkers of DNA damage in marine mammals. Mutation Research 444, 427-439.

Hall, A.J., Watkins, J., Hammond, P.S., 1998. Seasonal variation in the diet of harbour seals in the south-western North Sea. Marine Ecology Progress Series 170, 269-281.

Hobbs, K.E., Lebeuf, M., Hammill, M.O., 2002. PCBs and OCPs in male harbour, grey, harp and hooded seals from the Estuary and Gulf of St Lawrence, Canada. Science of the Total Environment 296, 1-18.

Hutchinson, J.D., Simmonds, M.P., 1994. Organochlorine contamination in pinnipeds. Reviews of Environmental Contamination and Toxicology 136, 123-167.

Jauniaux, T., Petitjean, D., Brenez, C., Borrens, M., Brosens, L., Haelters, J., Tavernier, T. Coignoul, F., 2002. Post-mortem findings and causes of death of harbour porpoises (Phocoena phocoena) stranded from 1990 to 2000 along the coastlines of Belgium and Northern France. Journal of Comparative Pathology 126, 243-253.

Johnson-Restrepo, B., Kannan, K., Addink, R., Adams, D.H., 2005. Polybrominated diphenyl ethers and polychlorinated biphenyls in a marine foodweb of coastal Florida. Environmental Science and Technology 39, 8243-8250.

Kajiwara, N., Kannan, K., Muraoka, M., Watanabe, M., Takahashi, S., Gulland, F., Olsen, H., Blankenship, A.L., Jones, P.D., Tanabe, S., Giesy, J.P., 2001. Organochlorine pesticides, polychlorinated biphenyls and butyltin compounds in blubber and livers of stranded California sea lions, elephant seals and harbour seals from coastal California, USA. Archives of Environmental Contamination and Toxicology 41, 90-99.

Kajiwara, N., Kamikawa, S., Ramu, K., Ueno, D., Yamada, T.K., Subramanian, A., Lam, P.K.S., Jefferson, T.A., Prudente, M., Chung, K.-H., Tanabe, S., 2006. Geographical distribution of polybrominated diphenyl ethers (PBDEs) and organochlorines in small cetaceans from Asian waters. Chemosphere 64, 287-295.

Law, R.J., Allchin, C.R., Bennett, M.E., Morris, S., Rogan, E., 2002. Polybrominated diphenylethers in two species of marine top predators from England and Wales. Chemosphere 46, 673-681.

Law, R.J., Alaee, M., Allchin, C.R., Boon, J.P., Lebeuf, M., Lepom, P., Stern, G.A., 2003. Levels and trends of polybrominated diphenylethers and other brominated flame retardants in wildlife. Environment International 29, 757-770.

Law, R.J., Allchin, C.R., de Boer, J., Covaci, A., Herzke, D., Lepom, P., Morris, S., Tronczynski, J., de Wit, C.A., 2006a. Levels and trends of brominated flame retardants in the European environment. Chemosphere 64, 187-208.

Law, R.J., Jepson, P.D., Deaville, R., Reid, R.J., Patterson, I.A.P., Allchin, C.R., Jones, B.R., 2006b. Collaborative UK Marine Mammals Strandings Project: summary of contaminant data for the period 1993-2001. Science Series Technical Report Cefas Lowestoft, 131, 72 pp.

Letcher, R.J., Klasson-Wehler, E., Bergman, A., 2000. Methyl sulfone and hydroxylated metabolites of polychlorinated biphenyls. In: Paasivirta, J. (Ed.), The Handbook of Environmental Chemistry, Vol. 3, Part K, New Types of Persistent Halogenated Compounds. Springer-Verlag, Berlin, Heidelberg.

Lydersen, C., Wolkers, H., Severinsen, T., Kleivane, L., Nordoy, E.S., Skaare, J.U., 2002 Blood is a poor substrate for monitoring pollution burdens in phocid seals. Science of the Total Environment 292, 193-203.

MAFF, 1994. Collaborative UK Marine Mammal Project: summary of data produced 1988-1992. Compiler: Law, R.J., 1994. Fisheries Research Technical Report, MAFF Directorate of Fisheries Research, 97, 42 pp.

Montie, E.W., Fair, P.A., Bossart, G.D., Mitchum, G.B., Houde, M., Muir, D.C.G., Letcher, R.J., McFee, W.E., Starczak, V.R., Stegeman, J.J., Hahn, M.E., 2008 Cytochrome P4501A1 expression, polychlorinated biphenyls and hydroxylated metabolites, and adipocyte size of bottlenose dolphins from the Southeast United States. Aquatic Toxicology 86, 397-412.
Mos, L., Tabuchi, M., Dangerfield, N., Jeffries, S.J., Koop, B.F., Ross, P.S., 2007 Contaminant-associated disruption of vitamin A and its receptor (retinoic acid receptor $\alpha$ ) in free-ranging harbour seals (Phoca vitulina). Aquatic Toxicology 81 319-328.

Reijnders, P.J.H., 1986. Reproductive failure in common seals feeding on fish from polluted coastal waters. Nature $324,456-457$.

Santos, M.B., Pierce, G.J., 2003. The diet of harbour porpoise (Phocoena phocoena) in the Northeast Atlantic. Oceanography and Marine Biology: An Annual Review 41, 355-390.

Severinsen, T., Skaare, J.U., Lydersen, C., 2000. Spatial distribution of persistent organochlorines in ringed seal (Phoca hispida) blubber. Marine Environmental Research 49, 291-302.

She, J., Petreas, M., Winkler, J., Visita, P., McKinney, M., Kopec, D., 2002. PBDEs in the San Francisco Bay Area: measurements in harbour seal blubber and human breast adipose tissue. Chemosphere 46, 697-707.

Shaw, S.D., Brenner, D., Bourakovsky, A., Mahaffey, C.A., Perkins, C.R., 2005 Polychlorinated biphenyls and chlorinated pesticides in harbour seals (Phoca vitulina concolor) from the North-Western Atlantic coast. Marine Pollution Bulletin 50, 1069-1084.

Shaw, S.D., Brenner, D., Berger, M.L., Fang, F., Hong, C.S., Storm, R., Hilker, D. O'Keefe, P., 2007. Organohalogen Compounds 69, 829-832.

Stapleton, H.M., Alaee, M., Letcher, R.J., Baker, J.E., 2004. Debromination of the flame retardant decabromodiphenyl ether by juvenile carp (Cyprinus carpio) following dietary exposure. Environmental Science and Technology 38, 112-119.

Stapleton, H.M., Dodder, N.G., Kucklick, J.R., Reddy, C.M., Schantz, M.M., Becker, P.R Gulland, F., Porter, B.J., Wise, S.A., 2006. Determination of HBCD, PBDEs and MeO-BDEs in California sea lions (Zalophus californianus) stranded between 1993 and 2003. Marine Pollution Bulletin 52, 522-531.

Tanabe, S., Iwata, H., Tatsukawa, R., 1994. Global contamination by persistent organochlorines and their ecotoxicological impact on marine mammals. Science of the Total Environment 154, 163-177.

Thomas, G.O., Moss, S.E.W., Asplund, L., Hall, A.J., 2005. Absorption of decabromodiphenyl ether and other organohalogen chemicals by grey seals (Halichoerus grypus). Environmental Pollution 133, 581-586.

Vetter, W., Luckas, B., Heidemann, G., Skirnisson, K., 1996. Organochlorine residues in marine mammals from the Northern hemisphere - a consideration of the composition of organochlorine residues in the blubber of marine mammals. Science of the Total Environment 186, 29-39.

Voorspoels, S., Covaci, A., Schepens, P., 2003. Polybrominated diphenyl ethers in marine species from the Belgian North Sea and the Western Scheldt estuary: levels, profiles and distribution. Environmental Science and Technology 37, 4348-4357.

Vorkamp, K., Christensen, J.H., Riget, F., 2004. Polybrominated diphenyl ethers and organochlorine compounds in biota from the marine environment of East Greenland. Science of the Total Environment 331, 143-155.

Weijs, L., Dirtu, A.C., Das, K., Gheorghe, A., Reijnders, P., Neels, H., Blust, R., Covaci, A., 2009. Inter-species differences for PCBs and PBDEs in marine top predators from the Southern North Sea: part 2. Biomagnification in harbour seals and harbour porpoises. Environmental Pollution 157, 445-471.

Wolkers, H., Lydersen, C., Kovacs, K., 2004. Accumulation and lactational transfer of PCBs and pesticides in harbour seals (Phoca vitulina) from Svalbard, Norway. Science of the Total Environment 319, 137-146.

Wolkers, H., Corkeron, P.J., Van Parijs, S.M., Similä, T., van Bavel, B., 2007. Accumulation and transfer of contaminants in killer whales (Orcinus orca) from Norway: indications for contaminant metabolism. Environmental Toxicology and Chemistry 26, 1582-1590. 